\title{
Regeneration and Colonization of an Invasive Macrophyte Grass in Response to Desiccation
}

\author{
Thaisa Sala Michelan ${ }^{1}$, Sidinei Magela Thomaz ${ }^{2, \star}$, Priscilla Carvalho ${ }^{3}$, \\ Roberta Becker Rodrigues ${ }^{3} \&$ Márcio José Silveira ${ }^{4}$
}

\author{
${ }^{1}$ Graduate Program in Ecology and Evolution, Universidade Federal de Goiás - UFG, \\ Campus II, CEP 74001-970, Goiânia, GO, Brazil \\ ${ }^{2}$ Biological Science Department/Nupélia, Universidade Estadual de Maringá - UEM, \\ Av. Colombo 5790, bloco H-90, CEP 87020-900, Maringá, PR, Brazil \\ ${ }^{3}$ Graduate Program in Ecology of Continental Aquatic Environments, Universidade Estadual de Maringá - UEM \\ ${ }^{4}$ Graduate Program in Comparative Biology, Universidade Estadual de Maringá - UEM
}

\begin{abstract}
The emergent macrophyte Urochloa subquadripara, an exotic and invasive species, causes extensive damage to aquatic plant assemblages. Regeneration and colonization by fragments of $U$. subquadripara may be affected by desiccation and may differ according to the fragment portion (apical, intermediate or basal). We tested the hypotheses that the ability of $U$. subquadripara fragments to regenerate and colonize declines with increasing time of exposure to desiccation, and that apical portions regenerate and colonize more quickly than intermediate and basal ones. Apical, intermediate and basal portions were exposed to different desiccation periods and left to grow in a greenhouse. Sprout and root growth were negatively and significantly affected by the desiccation period; fragments exposed to intermediate levels of desiccation regenerated and colonized the sediment at rates similar to those of the control. In addition, apical fragments showed greater development and sediment colonization than intermediate and basal fragments. Thus, the data supported our two hypotheses. Our results show that $U$. subquadripara has a high regeneration potential, indicating that the use of water drawdown to control its spread may be ineffective, and new strategies are required.
\end{abstract}

Key words: Non-Native Species, Urochloa subquadripara, Vegetative Propagation, Plant Dispersal, Tropical Signalgrass.

\section{Introduction}

Alien species are commonly introduced in freshwater ecosystems, where they threaten several natives. This phenomenon has become a central concern for freshwater ecologists and managers because inland aquatic ecosystems are often more diverse compared to terrestrial and marine ecosystems (Balian et al. 2008) and are experiencing high extinction rates (Jenkins 2003).

Several species of aquatic macrophytes are well suited to be successful invaders because they reproduce prolifically, disperse easily and are adapted to a myriad of habitats (Santamaria 2002). Understanding how alien plant species become invasive is a fundamental goal in invasion ecology (Rejmánek et al. 2005) and an essential component of vegetation dynamics (including alien species) is the

\footnotetext{
${ }^{*}$ Send correspondence to: Sidinei Magela Thomaz

Biological Science Department/Nupélia,

Universidade Estadual de Maringá - UEM,

Av. Colombo 5790, bloco H-90, CEP 87020-900,

Maringá, PR, Brazil

E-mail: smthomaz@nupelia.uem.br
}

ability of plants to colonize available habitats (Riis 2008). Spatial patterns of abundance may be determined by the biological characteristics of a species (e.g., its life form) and physical features of its environment (e.g., water and sediment physico-chemistry) (e.g., Henry-Silva et al. 2008). Dispersal by plant fragments is also an important mechanism contributing to plant regeneration and spatial patterns of species abundance (Riis et al. 2009). Regional recovery after disturbances should occur more rapidly in species with widespread dispersal owing to their ability to disseminate propagules over relatively large areas (Reed et al. 2000).

Vegetative propagation is a common dispersal strategy of many aquatic plants, and dispersal and colonization can take place through a variety of vegetative plant portions, including entire plants, rhizomes, stolons, tubers, turions and simple stem fragments (Barrat-Segretain \& Cellot 2007; Riis et al. 2009). Macrophyte fragments are released by several types of disturbance, such as sediment mobility, herbivory and changes in water flow (Riis \& Sand-Jensen 
2006). Fragments can travel considerable distances via water flow, water birds and boats, and they can initiate colonization in distant habitats (Santamaria 2002; Thomaz et al. 2009).

In wetlands, drying generally leads to biomass losses in the established vegetation (Combroux \& Bornette 2004). This process also occurs when reservoirs are subject to water drawdown (Thomaz et al. 2009). Thus, the water regime is a major determinant of aquatic-plant community development, and the time of exposure to desiccation of plant fragments is an important determinant of their growth and success in freshwater ecosystems (Barrat-Segretain \& Cellot 2007; Silveira et al. 2009).

Recent studies indicate that some troublesome exotic species can accumulate high biomasses (Pott VJ \& Pott A 2003; Thomaz et al. 2009; Michelan et al. 2010). One example is the Poaceae Urochloa subquadripara (Trin.) R.D. Webster [syn. Brachiaria subquadripara (Trin.) Hitchc., Brachiaria arrecta (Hack.) Stent.], commonly known as tropical signalgrass (Teuton et al. 2004). It is native to Africa, exhibits high invasion potential (Kissman 1997) and has colonized several natural and artificial aquatic ecosystems in Brazil (Pott VJ \& Pott A 2003; Thomaz et al. 2009) and in the United States (Teuton et al. 2004). According to Lorenzi (2000), this species propagates exclusively by stolons, although regeneration via seeds has also been reported (Teuton et al. 2004). Reservoirs and floodplains suffer water-level drawdown, which causes mortality of the emergent parts of tropical signalgrass (Thomaz et al. 2009; Michelan et al. 2010). Investigating the vegetative regeneration of this species is important to understand how it colonizes sediment and recovers from drought stress.

In this study, we investigated how vegetative fragments of U. subquadripara recover from desiccation. We hypothesized that (i) the ability of tropical signalgrass fragments to regenerate new sprouts and colonize sediment declines with increasing time of exposure to desiccation and (ii) younger portions (apical) of tropical signalgrass stems submitted to desiccation regenerate and colonize more quickly than older (basal) ones. According to these hypotheses, we tested the predictions that sprout and root biomass, sprout length and sprout and root RGR (Relative Growth Rates) are greater in younger fragments submitted to shorter desiccation periods. The rationale for this hypothesis is that macrophytes, particularly grasses, usually regenerate most quickly from apical fragments where meristematic activity is higher (Kissman 1997; Riis et al. 2009), and that desiccation represents a stress that may reduce regeneration (Silveira et al. 2009).

\section{Materials and Methods}

We collected tropical signalgrass and sediment from a floodplain lake (Upper Paraná River floodplain; $22^{\circ} 45^{\prime} 24^{\prime \prime} \mathrm{S}$ and $53^{\circ} 23^{\prime} 28^{\prime \prime} \mathrm{W}$ ) in January 2009 . The material was transported to the laboratory on the same day. The experiment was carried out from January to March 2009.
The mean daily photoperiod was 13 hours \pm 0.9 SD, the mean daily maximum temperature was $31.18^{\circ} \mathrm{C} \pm 2.33 \mathrm{SD}$ and the mean daily minimum temperature was $21.02^{\circ} \mathrm{C} \pm 1.48 \mathrm{SD}$.

Here, we consider regeneration to be the emergence of new sprouts and colonization to be rooting in sediment (sensu Barrat-Segretain \& Bornette 2000). To assess the period over which tropical signalgrass can resist desiccation, plants were kept in a tray without water for 2, 5, 9, 17 and 26 days. We did not choose these periods in advance, but they were chosen over the course of the experiment by analyzing regeneration. For example, fragments regenerated quickly after the first three desiccation periods, so the intervals between periods were short during the early portion of the experiment. However, regeneration was substantially lower after 17 days, so we extended the final period to 26 days of desiccation before finishing the experiment. After 26 days of desiccation, almost no regeneration occurred (see Results). Fragments not submitted to desiccation were used as controls (zero days of desiccation).

To evaluate differences in regeneration and colonization between different plant fragments, we used fragments from close to the tip (apical) and from the intermediate and basal portions of tropical signalgrass. From each portion, we selected a fragment with two nodes. Basal (close to the root) fragments are the oldest and apical (close to the tip) fragments are the youngest.

We added sediment and water to plastic trays $(45 \times 38 \times 9 \mathrm{~cm})$. The water layer in the trays was about $5 \mathrm{~cm}$ deep and was maintained by adding tap water every day. Three fragments from the same individual (apical, intermediate and basal portions) in each desiccation treatment (control, 2, 5, 9, 17 and 26 days of desiccation) were added to the trays. Thus, there were five trays (five replicates), each containing 18 fragments (three plant portions $\times$ six desiccation treatments).

For each fragment, the following biological attributes were measured after 26 days: dry weights (DW; g) of sprouts and roots, sprout length $(\mathrm{cm})$, relative growth rates (RGR) of sprout length and biomass, number of sprouts and number of leaves per fragment. We chose a maximum of 26 days of desiccation because this period was long enough to almost completely eliminate fragment regeneration (see Results). We measured DW after drying the plant material in an oven at $80{ }^{\circ} \mathrm{C}$ until a constant weight was reached. The RGRs were calculated for each sprout (following Radford 1967) based on its increase in length, according to the equation:

$\mathrm{RGR}=\left(\ln X_{\mathrm{t}}-\ln X_{\mathrm{t}-1}\right) / \Delta \mathrm{t}$

where $X_{t}=$ final length (26 days), $X_{\mathrm{t}-1}=$ length at the beginning of the experiment and $\Delta t=$ days of desiccation. Because sprout lengths were zero at the beginning, the equation became:

$\mathrm{RGR}=\ln X_{\mathrm{t}} / \Delta \mathrm{t}$ 
We used the same equation to estimate the RGR of sprout biomass, but with sprout dry weight substituted for length. Because each fragment had, in general, more than one sprout, the mean RGR per fragment was considered in the analyses. Because there were two nodes in each fragment, we summed the sprout and root dry weights and the number of sprouts and leaves; thus, these response variables became a single number per fragment.

An analysis of covariance (ANCOVA) was performed to test the homogeneity of slopes derived from the regression analysis, considering the relationship between dependent variables (sprout and roots biomass, mean sprout length, sprout length RGR and sprout biomass RGR) and the time of exposure to desiccation (in days) across the three different plant segments (apical, intermediate and basal) (Crawley 1993). In this analysis, the time of exposure to desiccation (in days) was considered to be the covariate.

The nonparametric Kruskal-Wallis test was used to analyze the effect of time of exposure to desiccation and plant segment (apical, intermediate and basal) on the numbers of sprouts and leaves. We used this nonparametric analysis because these response variables are discrete. We used the program STATISTICA 7.0 (StatSoft Inc. 2007) to perform the ANCOVA and the Kruskal-Wallis analysis.

\section{Results}

Desiccation negatively affected the regeneration and colonization of tropical signalgrass, and the apical, intermediate and basal portions responded differently to desiccation stress. Fragments not submitted to desiccation (control) or submitted to 2 days of desiccation had 100\% regeneration (i.e., all fragments emitted sprouts). A lesser but still high degree of regeneration was found after the 5 and 9 days of desiccation (93\%). Much lower regeneration occurred after 17 and 26 days of desiccation (40 and 13\%, respectively). Among plants submitted to 5 and 9 days of desiccation, only one basal fragment did not regenerate. Among plants submitted to 17 days of desiccation, regeneration did not occur in four basal fragments, three intermediate fragments and two apical fragments. However, only two intermediate fragments regenerated in the treatment submitted to 26 days of desiccation.

In general, all attributes were relatively stable from zero to 9 days of desiccation in fragments from the apical and intermediate segments, but a steep decrease occurred after 26 days of desiccation. In contrast, generally lower and constantly decreasing values with increasing time of exposure to desiccation were observed in the basal segments of tropical signalgrass (Figures 1 and 2).

After 26 days of growth, control fragments from the apical portion had the highest mean values of sprout $(0.26 \pm 0.08 \mathrm{SE} \mathrm{g} \mathrm{DW})$ and root biomass $(0.32 \pm 0.15 \mathrm{SE} g \mathrm{DW})$. Desiccation period and fragment position negatively and significantly affected sprout and root biomasses, but the interaction between desiccation period and position was not significant (Table 1; Figure 1a, b). The greatest mean sprout length was also recorded for the apical portion in the control $(18.02 \pm 3.73 \mathrm{SE} \mathrm{cm})$; however, at least one intermediate fragment exhibited a tall sprout, even after 17 days of desiccation $(25.6 \mathrm{~cm})$. The mean sprout length was also negatively and significantly affected by the desiccation period and fragment position (Table 1; Figure 1c). The interaction was not significant (Table 1).

The sprout-length RGR and sprout-biomass RGR decreased significantly with days of desiccation. These variables were also affected significantly by fragment position (Table 1; Figure 1d, e). For both variables, the interactions were not significant (Table 1). The highest mean sprout length RGR $\left(0.11 \pm 0.009 \mathrm{SE} \mathrm{d}^{-1}\right)$ and sprout biomass RGR $\left(0.008 \pm 0.002 \mathrm{SE} \mathrm{d}^{-1}\right)$ were found for the apical fragment in the control treatment, corresponding to doubling times of 6 and 86 days, respectively. However, the lowest mean sprout length and biomass RGR values were close to zero in the three types of fragments after 26 days of desiccation.

In contrast to the other variables, the mean number of sprouts was highest in the intermediate fragments after 5 days of desiccation ( $2.2 \pm 0.2 \mathrm{SE})$, and the highest number of leaves was found in apical fragments in the same treatment $(9.6 \pm 0.7 \mathrm{SE})$. Both variables were negatively and significantly affected by desiccation period and fragment position (Table 2; Figure 2a, b).

Table 1. Results of an ANCOVA for effects of fragment position (apical, intermediate and basal) and desiccation (0, 2, 5, 9, 17 and 26 days) and their interactions on sprout biomass, root biomass, sprout lenght, sprout-lenght RGR and sprout-biomass RGR.

\begin{tabular}{lcrc}
\hline & DF & F & P \\
\hline Sprout biomass (g) & & & \\
$\quad$ Fragment position & 2 & 14.71 & $<0.001$ \\
Days of desiccation & 1 & 41.26 & $<0.001$ \\
$\quad$ Interaction & 2 & 2.62 & 0.079 \\
Root biomass (g) & & & \\
$\quad$ Fragment position & 2 & 9.41 & $<0.001$ \\
$\quad$ Days of desiccation & 1 & 26.21 & $<0.001$ \\
$\quad$ Interaction & 2 & 1.81 & 0.169 \\
Mean sprout length (cm) & & & \\
$\quad$ Fragment position & 2 & 8.25 & 0.001 \\
$\quad$ Days of desiccation & 1 & 77.81 & $<0.001$ \\
$\quad$ Interaction & 2 & 0.83 & 0.44 \\
Sprout-length RGR & & & \\
Fragment position & 2 & 3.4 & 0.038 \\
$\quad$ Days of desiccation & 1 & 128.6 & $<0.001$ \\
$\quad$ Interaction & 2 & 0.1 & 0.868 \\
Sprout-biomass RGR & & & \\
$\quad$ Fragment position & 2 & 14.73 & $<0.001$ \\
Days of desiccation & 1 & 45.6 & $<0.001$ \\
Interaction & 2 & 2.5 & 0.089 \\
\hline
\end{tabular}



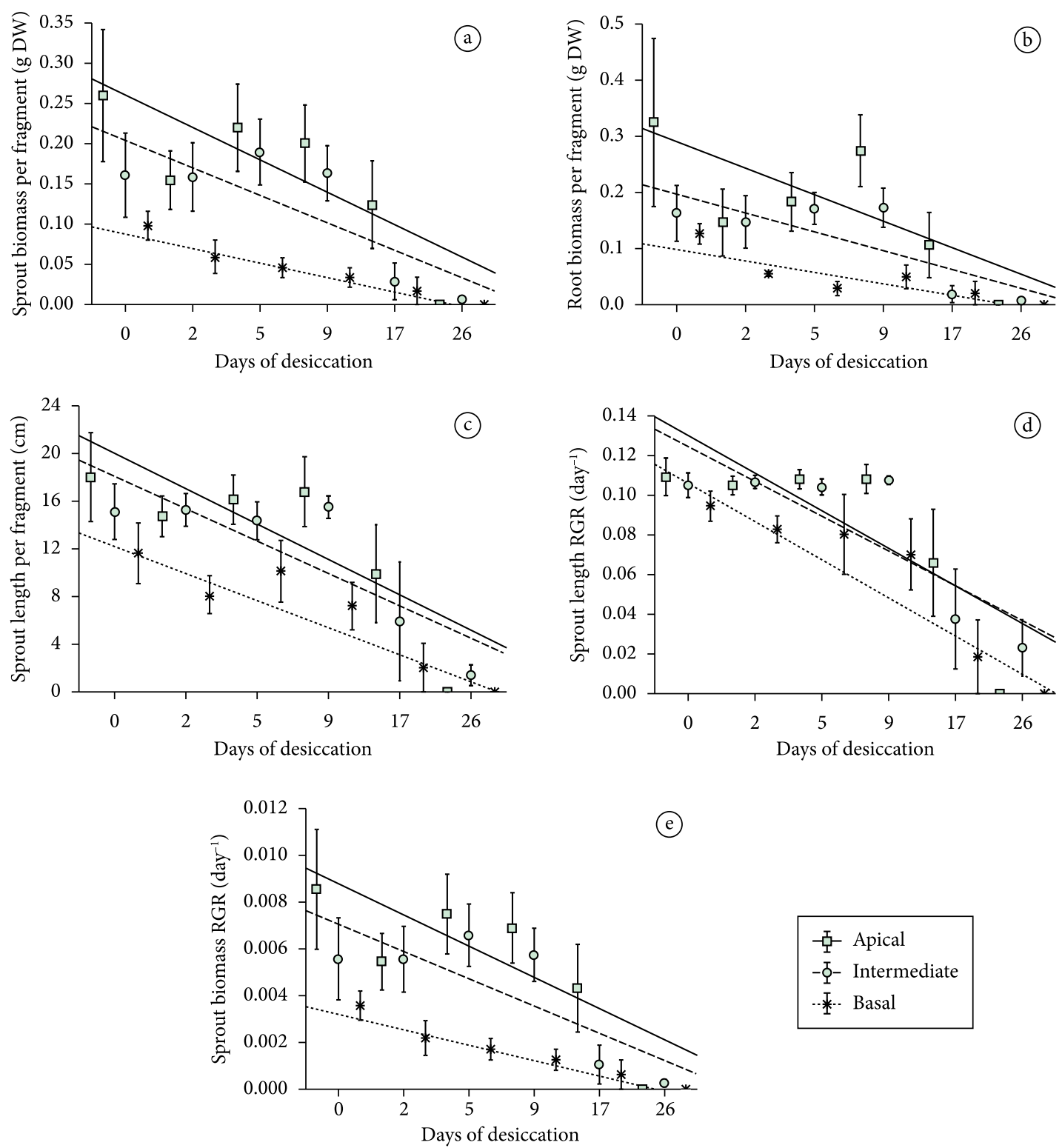

Figure 1. Sprout biomass a), root biomass b), sprout length c), and RGRs measured for sprout length d) and biomass e) of fragments of Urochloa subquadripara taken from apical (closer to the tip), intermediate and basal parts of the plant. Attributes were measured across different desiccation periods. Mean values and standard errors of five replicates are shown. Lines represent ordinary leastsquares fits.

\section{Discussion}

Several species of the family Poaceae are invasive in terrestrial (Kissman 1997; Petenon \& Pivello 2008) or freshwater aquatic ecosystems (Douglas \& O'Connor 2003; Michelan et al. 2010). The success of plant invaders can be explained by several features, such as their ability to reproduce vegetatively, high growth rates, high seed production, high seed germination rates, easy dispersal, short life cycles and production of allelopathic agents (Elton 1958; Pyšek et al. 2008). These features are common in several species of the family Poaceae (e.g., Urochloa mutica and Urochloa subquadripara, our target species).
Vegetative reproduction via stolons is common in Poaceae (Kisssman 1997). This ability to reproduce by stolons is due in part to the presence of culms (i.e., grass stems), which are segmented by nodes. Nodes in Poaceae are the regions with the highest meristematic activity and where roots, branches and other culms originate (Kissman 1997). Thus, nodes have the potential to originate new individuals. Our results show a high degree of regeneration (emission and growth of sprouts and roots) and colonization (rooting in sediment) from the nodes of tropical signalgrass. Although we are not aware of studies addressing the growth and regeneration of tropical signalgrass, high growth rates (Bianchini Jr. et al. 2010) and regeneration rates (greater 

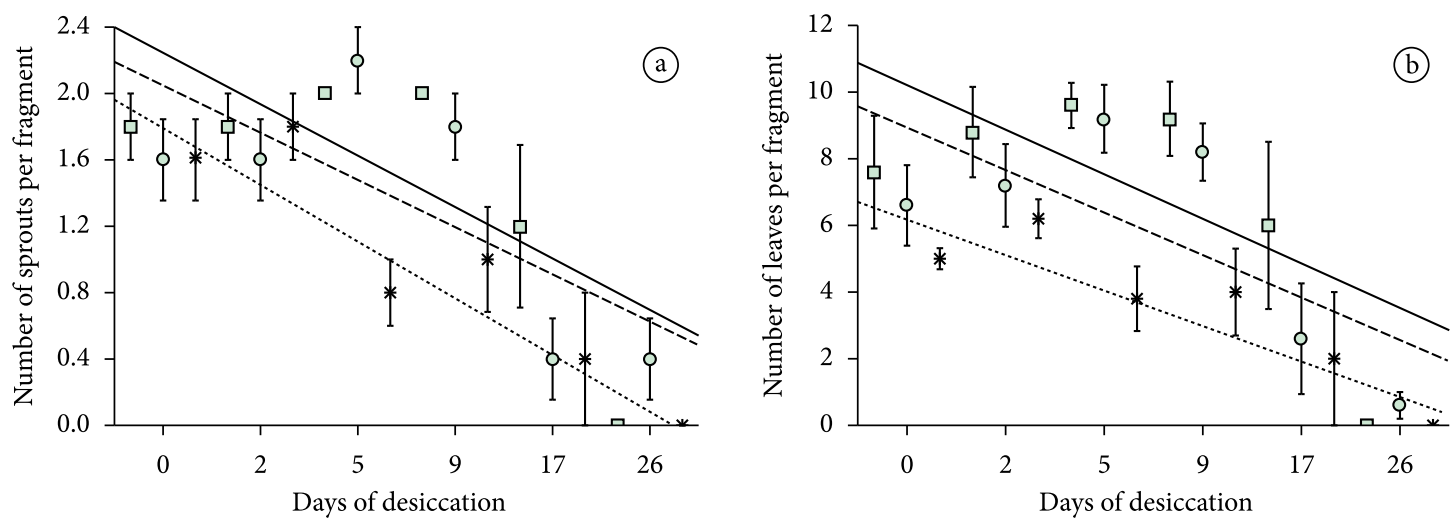

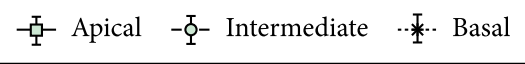

Figure 2. Numbers of sprouts a) and leaves b) per fragment of Urochloa subquadripara taken from apical (closer to the tip), intermediate and basal parts of the plant. Attributes associated with regeneration were measured across different desiccation periods. Mean values and standard errors of five replicates are shown.

Table 2. Results of a Kruskal Wallis test for effects of fragment position (apical, intermediate and basal) and desiccation $(0,2,5$, 9,17 and 26 days) on the numbers of sprouts and leaves.

\begin{tabular}{lcrr}
\hline & DF & H & \multicolumn{1}{c}{ P } \\
\hline Number of sprouts & & & \\
Fragment position & 2 & 6.91 & 0.031 \\
$\quad$ Days of desiccation & 5 & 42.73 & $<0.001$ \\
Number of leaves & & & \\
Fragment position & 2 & 12.68 & 0.001 \\
Days of desiccation & 5 & 35.05 & $<0.001$ \\
\hline
\end{tabular}

than $60 \%$ ) are common in other invasive macrophytes (Barrat-Segretain \& Bornette 2000; Barrat-Segretain \& Cellot 2007; Riis et al. 2009). However, regeneration of some macrophyte species is higher when fragments contain the apical tips (Riis et al. 2009). For tropical signalgrass, regeneration does not depend on the presence of apical tips; we obtained $100 \%$ regeneration from all fragment positions in the control treatment. This high regeneration rate may partly explain the high frequency of occurrence of tropical signalgrass (Pott VJ \& Pott A 2003; Thomaz et al. 2009) and its impacts on natives (Michelan et al. 2010).

However, even though intermediate and basal fragments were capable of regenerating, both regeneration and colonization were more likely in fragments taken from closer to the apical portion of the parent plants, which are younger than the basal fragments. Younger tissues of macrophytes such as Potamogeton perfoliatus L. and Elodea canadensis Michx. exhibit higher meristematic activity than older tissues (Riis et al. 2009); this pattern is consistent with our results.

Notably, our results indicate that tropical signalgrass is highly resistant to desiccation stress: some regeneration occurred even after 26 days of desiccation. These results have practical implications. For example, water level drawdown is a strategy suggested to control aquatic macrophytes in some situations (Wade 1990). However, our results indicate that plans meant to control and manage tropical signalgrass will not succeed if short-term drawdowns are used.

The responses of regeneration and colonization to desiccation stress vary in different macrophyte species. Following intermediate desiccation periods (i.e., a few days of drought), for example, some species may grow and develop faster, leading to successful colonization (Riss et al. 2009) and changing the composition and structure of macrophyte assemblages (Hill et al. 1998). Results similar to ours (i.e., high rates of regeneration and colonization even after 9 days of desiccation) have been found for other species of aquatic macrophytes, such as Elodea nuttallii (Planchon) St. John, Hydrilla verticillata (L. f.) Royle, Egeria najas Planch. and Egeria densa Planch., whose survival rates and sprout and root lengths did not differ between various desiccation periods and controls (Barrat-Segretain \& Cellot 2007; Silveira et al. 2009).

In an experiment using herbicide, Carbonari et al. (2003) have shown that tropical signalgrass is difficult to control and that the regeneration of this species is even higher when an intermediate level of herbicide is used. Although herbicide and desiccation affect plant physiology differently, both are sources of plant of stress; thus, it seems that intermediate levels of stress may actually increase the regeneration of tropical signalgrass.

In summary, our data support the hypothesis that regeneration of new sprouts and colonization of the sediment decline with increasing time of exposure to desiccation in tropical signalgrass fragments. Desiccation negatively and significantly affected all attributes that we measured (sprout and root biomasses, mean sprout length, sprout length RGR, sprout biomass RGR and the numbers of sprouts and leaves). However, these results are valid only for longer periods of desiccation ( $>10$ days); at intermediate levels of desiccation (up to 9 days), fragments regenerated and 
colonized sediments quite well. Our hypothesis that younger portions of this species are more likely to regenerate and colonize than older ones was also supported; fragments taken from closer to the apical portions grew and colonized sediments more often than those taken from farther from the apical portions.

Finally, we contend that the presence of $U$. subquadripara in reservoirs with different surface areas, and in natural ecosystems such as streams and lakes, is a matter of concern because this species significantly affects the richness and composition of native macrophyte assemblages (Michelan et al. 2010). The easy regeneration of this species via fragments, as shown by our experiments, increases this concern. Any mechanical management strategy that produces fragments of $U$. subquadripara may not be efficient. Our results emphasize that controlling this species is difficult and that if water drawdown is applied, it will be effective only if long desiccation periods are used.

\section{Acknowledgments}

P. Carvalho and M. J. Silveira thank the Parque Tecnológico da Itaipu (PDTA/FPTI-BR) and T. S. Michelan acknowledges the Brazilian Council of Research (CNPq) for providing scholarships. S. M. Thomaz is especially thankful to $\mathrm{CNPq}$ for continuous funding through a Research Productivity Grant. This research was funded by $\mathrm{CNPq} /$ Ministério da Ciência e Tecnologia through the Long-Term Ecological Research Program (site number 6) and Itaipu Binacional.

\section{References}

Balian JH et al., 2008. The Freshwater Animal Diversity Assessment: an overview of the results. Hydrobiologia, 595:627-637.

Barrat-Segretain MH \& Bornette G, 2000. Regeneration and colonization abilities of aquatic plant fragments: effect of disturbance seasonality. Hydrobiologia, 421:31-39.

Barrat-Segretain MH \& Cellot B, 2007. Response of invasive macrophyte species to drawdown: The case of Elodea sp. Aquatic Botany, 87:255-261.

Bianchini Jr. I et al., 2010. Growth of Hydrilla verticillata (L.f.) Royle under controlled conditions. Hydrobiologia, 644:301-312.

Carbonari CA et al., 2003. Controle de Brachiaria subquadripara e Brachiaria mutica através de diferentes herbicidas aplicados em pós-emergência. Planta Daninha, 21:79-84

Combroux ICS \& Bornette G, 2004. Propagule banks and regenerative strategies of aquatic plants. Journal of Vegetable Science, 15:13-20.

Crawley MJ, 1993. GLIM for ecologists. Oxford: Blackwell Scientific Publications.

Douglas MM \& O'Connor RA, 2003. Effects of the exotic macrophyte, para grass (Urochloa mutica), on benthic and epiphytic macroinvertebrates of a tropical floodplain. Freshwater Biology, 48:962-971.
Elton CS, 1958. The Ecology of Invasions by Animals and Plants, Methuen: The University of Chicago Press.

Henry-Silva GG et al., 2008. Growth of free-floating aquatic macrophytes in different concentrations of nutrients. Hydrobiologia, 610:153-160.

Hill NM et al., 1998. A hydrological model for predicting the effects of dams on the shoreline vegetation of lakes and reservoirs. Environmental Management, 22:723-736.

Jenkins M, 2003. Prospects for biodiversity. Science, 302:1175-1177.

Kissman KG, 1997. Plantas infestantes e Nocivas. São Paulo: BASF. Tomo I.

Lorenzi H, 2000. Plantas daninhas do Brasil: terrestres, aquáticas, parasitas e tóxicas. São Paulo: Nova Odessa.

Michelan TS et al., 2010. Effects of an exotic-invasive macrophyte (tropical signalgrass) on native plant community composition, species richness and functional diversity. Freshwater Biology, 55:1315-1326.

Petenon D \& Pivello VR, 2008. Plantas invasoras: representatividade da pesquisa dos países tropicais no contexto mundial. Natureza \& Conservação, 6:65-77.

Pott VJ \& Pott A, 2003. Dinâmica da vegetação aquática do Pantanal. In: Thomaz SM \& Bini LM (Ed.). Ecologia e manejo de macrófitas aquáticas. Maringá: Eduem. p. 145-162.

Pyšek P et al., 2008. Geographical and taxonomic biases in invasion ecology. Trends in Ecology \& Evolution, 23:237-244.

Radford PJ, 1967. Growth analysis formulae: their use and abuse. Crop Science, 7:171-175

Reed DC et al., 2000. The role of dispersal and disturbance in determining spatial heterogeneity in sedentary organisms. Ecology, 81:2011-2026.

Rejmánek M et al., 2005. Ecology of invasive plants: State of the art. In: Moody HA et al. (Ed.). Invasive alien species: a new synthesis. Washington: Island Press. p. 104-162.

Riis T \& Sand-Jensen K, 2006. Dispersal of plant fragments in small streams. Freshwater Biology, 51:274-286.

Riis T, 2008. Dispersal and colonisation of plants in lowland streams: success rates and bottlenecks. Hydrobiologia, 596:341-351.

Riis T et al. 2009. Regeneration, colonisation and growth rates of allofragments in four common stream plants. Aquatic Botany, 90:209-212.

Santamaria L, 2002. Why are most aquatic plants widely distributed? Dispersal, clonal growth and small-scale heterogeneity in a stressful environment. Acta Oecologica, 23:137-154.

Silveira MJ et al., 2009. Effects of desiccation and sediment type on early regeneration of plant fragments of three species of aquatic macrophytes. International Review of Hydrobiology, 94:169-178.

StatSoft Inc, 2007. STATISTICA. Data analysis software system. Version 8.0. Available from: <www.statsoft.com>. 
Teuton TC et al., 2004. Factors affecting seed germination of tropical signalgrass (Urochloa subquadripara). Weed Science, 52:376-381.

Thomaz SM et al., 2009. Temporal trends and effects of diversity on occurrence of exotic macrophytes in a large reservoir. Acta Oecologica, 35:614-620.
Wade PM, 1990. Physical control of aquatic weeds. In: Pieterse AH \& Murphy KJ (Ed.). Aquatic weeds. The ecology and management of nuisance aquatic vegetation. Oxford: Oxford Science Publications. p. 93-135.

Received: August 2010

First Decision: August 2010

Accepted: September 2010 